\title{
Alitretinoin - molecular and cellular mechanisms of action
}

\author{
Andreas Kislat ${ }^{1 *}$, Stephan Meller ${ }^{1}$, Rodrigo Mota ${ }^{1}$, Peter A Gerber ${ }^{1}$, Bettina A Buhren ${ }^{1}$, Erich Bünemann', \\ Ulrike Wiesner", Thomas Ruzicka², Bernhard Homey ${ }^{1}$ \\ From 6th European Workshop on Immune-Mediated Inflammatory Diseases \\ Nice, France. 23-25 November 2011
}

\section{Background}

Chronic hand eczema (CHE) represents an inflammatory skin disease with a high prevalence ranging from $7-12 \%$ in Western industrialized countries. It was only starting from 2008 that the first, and until now the only, systemic treatment option, i.e. oral alitretinoin was approved in several countries for severe CHE unresponsive to potent topical corticosteroids. However, as the precise mechanism of actions (MOA) of alitretinoin in CHE are so far unknown, we undertook following investigations in order to shed some light on potential underlying immunomodulatory mechanisms.

\section{Materials and methods}

To investigate the mode of action of alitretinoin we stimulated human primary keratinocytes as well as leukocyte subsets and performed quantitative real-time PCR analyses, FACS-analyses, cell-proliferation assays as well as mixed leukocyte reactions (MLR).

\section{Results}

Alitretinoin acts on keratinocytes as well as dendritic cells. Keratinocytes show a significant reduction of chemokine expression after stimulation with alitretinoin whereas on dendritic cells alitretinoin inhibits the upregulation of the maturation marker CD83 as well as the co-stimulatory molecules CD80 and CD86. Consequently, alitretinointreated dendritic cells show significantly impaired $\mathrm{T}$ cell activating properties. Further analyses demonstrated that the immunomodulatory effect of alitretinoin results in a marked suppression of allogenic proliferation of leukocytes in MLR.

'Dept. of Dermatology, Heinrich-Heine University Hospital, Duesseldorf, Germany

Full list of author information is available at the end of the article

\section{Conclusions}

Taken together, these results suggest that alitretinoin modulates innate as well as adaptive immune responses by suppression of chemokine-induced leukocyte recruitment and inhibition of dendritic cell-mediated $\mathrm{T}$ cell activation.

\section{Author details}

${ }^{1}$ Dept. of Dermatology, Heinrich-Heine University Hospital, Duesseldorf, Germany. ${ }^{2}$ Dept. of Dermatology, Ludwig-Maximilians-University, Munich, Germany.

Published: 23 November 2011

doi:10.1186/1479-5876-9-S2-P16

Cite this article as: Kislat et al:: Alitretinoin - molecular and cellular mechanisms of action. Journal of Translational Medicine 2011 9(Suppl 2): P16.
Submit your next manuscript to BioMed Central and take full advantage of:

- Convenient online submission

- Thorough peer review

- No space constraints or color figure charges

- Immediate publication on acceptance

- Inclusion in PubMed, CAS, Scopus and Google Scholar

- Research which is freely available for redistribution
() Bïomed Central
C Biomed Central 